\title{
Finansal Bilgi Manipülasyonu ve Yaratıcı Muhasebeye İlişkin Meslek Mensupları Üzerine Bir Araştırma"
}

\author{
Hakkı AKMAN $^{* *} \quad$ Ferhat BİTLISLI ${ }^{* * *}$
}

\begin{abstract}
$\ddot{O} Z$
Sürekli değişen ve kendini yenileyen ekonomik gelişmeler neticesinde işletmeler hedeflerine ulaşmak için çeşitli faaliyetlerde bulunabilmektedirler. Bu faaliyetleri yasal mevzuattan kaynaklanan eksiklikler ve esnekliklerden yararlanarak muhasebe ve finansal veriler üzerinde değişiklik yaparak veya verileri hiç göstermeyerek, muhasebe manipülasyonun bir yöntemi olan yaratıcı muhasebe uygulamalart ile gerçekleştirmektedirler.

Bu tür uygulamalar ile finansal bilgi kullanıcılarının manipüle edilmiş bilgilere erişimi sağlanmakta ve işletme hakkında oluşan algılarının istenildiği şekilde yönlendirilmesine neden olmaktadır.

Bu şekilde oluşan manipülatif eylemlerin kontrolü ve uygulamaya geçiş noktası işletmelerin finansman ve muhasebe birimleridir. Muhasebe meslek mensuplarl görevleri gereği mükellefler ile kamu kurumları arasında köprü görevi görmektedirler. Bu nedenden dolayl gerçekleşen vergiye tabi her türlü faaliyette kayıt tutmak suretiyle mevzuatta gerekli olan görevleri yerine getirmek zorundadırlar. Bu görevler yerine getirilirken manipülatif uygulamalar, hata ve hile gibi unsurlarda meslek mensupları tarafindan suiistimal edilerek yapılabileceği öngörülmektedir.

Bu çalışmada muhasebe meslek mensuplarının yaratıcı muhasebe hakkında düşüncelerini tespit etmek amactyla ankete dayalı bir araştırma yapılmıştır. Elde edilen veriler $t$-testi (IndependentSamples T Test) aracıllğıyla test edilmiş katılımcıların düşünceleri ile sonuçlar ortaya çıkarılmıştır.

Anahtar Kelimeler: Finansal Bilgi, Finansal Bilgi Manipülasyonu, Yaratıcı Muhasebe

JEL Sinıflandırması: $M 41$
\end{abstract}

\section{A Research for Accounting Professionals on Financial Information Manipulation and Creative Accounting}

\begin{abstract}
As a result of constantly changing and self-renewing economic developments, businesses can carry out various activities to achieve their goals. These activities are carried out by taking advantage of deficiencies and flexibility arising from the legal legislation. Making changes to accounting and financial data or not showing data at all is an example of creative accounting practices which is a method of accounting manipulation. Such practices cause financial information users to access manipulated information. At the same time, it enables the perceptions about the company to be directed as desired.

The control point of such manipulative actions is the accounting units of the enterprises. Due to their duties, professional accountants act as bridges between taxpayers and public institutions.

\footnotetext{
* Bu makale Hakkı Akman tarafından hazırlanan " Finansal Bilgi Manipülasyonu ve Yaratıcı Muhasebeye İlişkin Meslek Mensupları Üzerine Bir Araştırma" (Danışman: Dr Öğr. Üyesi. Ferhat Bitlisli) adlı yüksek lisans çalışmasından hazırlanmıştır.

${ }_{* *}^{*}$ Muhasebe Bilim Uzmanı, Mehmet Akif Ersoy Üniversitesi Sosyal Bilimler Enstitüsü, Muhasebe ve Finansal Yönetim ABD, hakkiakman@gmail.com, ORCID Bilgisi: 0000-0001-9393-2736

*** Dr. Öğr. Üyesi. Mehmet Akif Ersoy Üniversitesi Zeliha Tolunay Uygulamalı Teknoloji ve İşletmecilik Yüksekokulu, Muhasebe ve Finansal Yönetim ABD, fbitlisli@mehmetakif.edu.tr , ORCID Bilgisi: 0000-0003$1638-8786$
} 
For this reason, they are obliged to keep records of all taxable activities and perform the duties defined in the legislation. It is envisaged that members of the profession may intervene in manipulative practices while performing their duties.

In this study, a survey-based research was conducted to determine the opinions of professional accountants about creative accounting. Obtained data were tested by means of $t$-test (Independent-Samples T Test). In the conclusion part, the results of the participants' thoughts were revealed.

Key Words: Financial Information, Manipulation, Creative Accounting

JEL Classification: M41

\section{GíRiş}

Finansal bilgi ihtiyacı duyan ve elde edindikleri finansal bilgiler 1şığında yatırım kararı düşüncesinde olan kişilerin veya grupların karar almalarında etkin bir görev üstlenen işletmeler finansal bilgilerin oluşturulmasında, analiz edilip oluşturulması noktasında Genel Kabul Görmüş Muhasebe İlkelerine ve Uluslararası Finansal Raporlama Standartlarına uygun bir şekilde ahlak ve etik kurallara uymak zorundadırlar.

Uyulmak zorunda olan bu kriterler global anlamda ve finansal anlamda bilgi alma ve bu alınan bilgiler neticesinde yatırım düşüncesinde bulunan bireylere yapmış oldukları veya yapacakları yatırımın gerçek, tarafsız ve şeffaf bir şekilde sunulması için oluşturulmuştur. Buna rağmen Genel Kabul Görmüş Muhasebe İlkelerine ve Uluslararası Finansal Raporlama Standartlarının esneklik ve boşluklarından yararlanılarak finansal bilgiler üzerinde farklılıklar oluşturulabilmektedir.

$\mathrm{Bu}$ esneklik ve boşluklar sayesinde işletme yöneticileri kendi menfaatleri ve işletmenin çıkarlarını gözeterek bilgileri diledikleri gibi yönlendirebilmektedirler. $\mathrm{Bu}$ şekilde oluşan esneklik ve boşlukların işletmeler tarafından etkin bir şekilde kullanılması durumuna "yaratıcı muhasebe kavramı" olarak adlandırabiliriz. Yaratıcı muhasebe uygulamaları işletmenin gerçekte oluşan değiştirilmemiş ham bilgilerini almakta bir engel oluşturmaktadır. Anlık oluşan maddi kazançlar çok cazip ve teşvik edici görünse de uzun vadede işletmelerin zarar edip, iflasına götüren bir süreç izlemektedir. Bu çalışmanın temel amacı finansal bilgi kullanıcılarının elde etmek istedikleri finansal bilgilerde yaratıcı muhasebe uygulamaları hakkında bilgi vermek ve ilgili muhasebe meslek mensuplarının bu konu hakkında bilgi seviyelerini belirleyerek, maruz kaldıkları yaratıcı muhasebe uygulamalarını tespit etmektir.

Bu kapsamda yapılan çalışma dört bölümden oluşarak ilk bölümde finansal bilgi manipülasyonları ile ilgili kavramsal bilgilere değinilmiştir. İkinci bölümde, yaratıcı muhasebenin tanımı, yaratıcı muhasebe uygulamaları ve yöntemleri hakkında bilgiler verilmiştir. Çalışmanın üçüncü bölümünde araştırmanın amacı kapsamı ve nasıl bir yöntem uygulandığı hakkında bilgiler verilerek yapılan anket çalışması doğrultusunda bilimsel verilere ulaşılmaya çalışılmıştır. Çalışmanın sonuç kısmında ise yapılan çalışma neticesinde ulaşılan bulgular ışı̆̆ında bazı önerilerde bulunulmuştur. 


\section{KAVRAMSAL ÇERÇEVE}

\section{A. Finansal Bilgi Manipülasyonu Kavramı ve Amaçları}

Finansal bilgi manipülasyonu, sermaye piyasalarına konu olan, alım satımla ilişkili finansal varlıklarda meydana gelen fiyatlara kabul edilebilir ya da gerçek bir sebep olmaksızın etki edilmesi, manipülasyonu gerçekleştiren kişi ve kişilerin kendi istek ve amaçlarına yönelik menfaatler elde etmesi, bu doğrultuda yatırımcıları yanlış yönlendirmesi durumlarını kapsayan işlemlerin ve eylemlerin tamamıdır (Bayındır, 2010, s. 71).

Bir diğer tanıma göre finansal bilgi manipülasyonu, bir işletmenin ekonomik durumunu iyi göstermek için işletme yöneticilerinin veya çıkar sağlayan grupların finansal bilgileri kendi iradeleri ile makyajlayıp usulsüz şekilde beyan etmeleri olarak ifade edilebilir (Trussel, 2003, s. 616). Finansal bilgi manipülasyonu; bilinçli ve kasıtlı olarak yapılan düzensizliklerle, işletmenin içinde bulunduğu finansal durumu olduğundan farklı gösterme ve böylelikle finansal bilgi kullanıcılarını yanıltma faaliyetlerinin bütünüdür. (Bayırlı, 2006, s. 28).

Finansal bilgi manipülasyonu, borçlanma maliyetlerini düşürmek, politik maliyet etkisini azaltmak, teşvik primleri etkisini arttırmak ve hisse senedi fiyatlarını yükseltmek amaçları ile yapılmaktadır. Borçlanma maliyetlerini düşürmek amaciyla gerçekleştirilen manipülasyonlar; şirketin kredibilitesini arttırmak, daha yüksek borçlanma derecesi ve daha düşük borçlanma maliyetlerine ulaşmak, kredi sözleşmelerinde daha esnek finansal koşullar elde etmek vb. faydaları ortaya çıkarmak amacı gütmektedir (Kirschenheiter \& Melumad, 2002, s. 763). İşletmelerde finansal bilgi manipülasyonu uygulayan yöneticiler, işletmeye yatırım düşüncesinde olan kişilere, kredi veren kredi kuruluşlarına ve devletin ilgili birimlerini etkileyici amaç içerisinde bulunmaktadırlar. Böylelikle işletme hakkında yatırım kararı içerinde bulunanların algılarında olumlu bir düşünce yapısı oluşmasını sağlamaktadır (Varıcı ve Er, 2013, s. 44). Politik maliyet etkisini azaltmaya yönelik gerçekleştirilen manipülasyonlar; daha yüksek vergi ödemekten kaçınma gibi amaçlarla ortaya çıkmaktadır. Teşvik primleri etkisini arttırmaya yönelik olarak gelişen manipülasyonlar; yöneticilerin raporlanan dönemsel kar üzerinden elde edebilecekleri primleri arttırmak amaciyla meydana gelmektedir. Hisse senedi fiyatlarını yükseltmek amacıyla gerçekleştirilen manipülasyonlar ise; hisse senedi fiyatları üzerinde gerçekleşen fiyat dalgalanmalarını azaltmak, sermaye maliyetlerini düşürmek ve hisse senedi opsiyonlarının değerini arttırmak amaçları ile ortaya çıkmaktadır (Dalğar \& Pekin, 2011, s. 26).

Tablo 1: Finansal Bilgi Manipülasyonunun Amaçları

\begin{tabular}{|l|l|}
\hline Amac & \multicolumn{1}{|c|}{ Sonucunda Sağlanan Favda } \\
\hline \multirow{3}{*}{ Hisse Senedi Fiyatı Etkisi } & - Yüksek hisse senedi fiyatı, \\
& - Hisse senedi fiyat dalgalanmasının azalması, \\
& - Şrket değerinin yükselmesi, \\
& - Sermaye maliyetinin düşmesi, \\
& - Hisse senedi opsiyonlarının değerinin artması. \\
\hline & - Kredibilitenin artması, \\
& - Daha yüksek borçlanma derecesi, \\
Borçlanma Maliyeti Etkisi & - Daha düšük borçlanma maliyeti, \\
& - Kredi sözleşmelerinde daha esnek finansal koşullar. \\
\hline
\end{tabular}


Hakkı Akman \& Ferhat Bitlisli / Finansal Bilgi Manipülasyonu ve Yaratıcı Muhasebeye İlişkin Meslek Mensupları Üzerine Bir Araştırma

\begin{tabular}{|l|l|}
\hline Teşvik Primleri Etkisi & - Kâra bağlı teşvik primi tutarının yükselmesi. \\
\hline Politik Maliyet Etkisi & - Düzenlemelerin azalması, \\
& - Daha yüksek vergiden kaçınma. \\
\hline
\end{tabular}

Kaynak: Mulford W. Charles ve Comiskey Eugune E.: "The Financial Numbers Game: Detecting Creative Accounting Practices", Canada, 2002, s. 4.

\section{B. Manipülasyon, Hata ve Hile Arasındaki Farklılıklar}

Finansal bilgi sağlayıcı unsurların tahrip edilip değiştirilmesi sonucunda karşılaştı̆̆ımız manipülasyon, hata ve hile kavramları birbirlerine çok yakın ifadeler olsa bile, kendilerini ayırt edici ince çizgileri bulunmaktadır. Kavramsal anlamda işleyişe yön verme değiştirme durumlarının bütününe manipülasyon faaliyeti denilmektedir. Bu durum isteyerek ya da farkında olmadan bilinçsizce gerçekleşebilir. Bu durumu bir örnekle açıklayacak olursak, bir işletmenin mali dönem sonunda yapılan envanter işleminin sonucunda olması gerekenden farklı ortaya çıkan bilgiler ile mevcut dönemin satış maliyetini çıkaracak olursak bunu bir manipülasyon işlemi olarak değerlendirmemiz gerekecektir. Fakat bu durumun isteyerek mi yoksa sehven mi yapıldığına karar vermemiz güçtür.

Hata ve hile kavramlarının içeriğinde yönlendirme ve değiştirme işlemlerine söz konusu olan kalemlerinin bilerek isteyerek kasitlı bir şekilde yapılması durumu hileyi, istemeden bilmeden dikkatsizlik ve dalgınlı sebebi ile sehven yapılan yönlendirme ve değişikliler ise hata kapsamında incelenmektedir (Genç \& Köse, 2018, s. 29-30).

Yapılan manipülatif eylem neticesinde ortaya çıkan sonuçtan karşı taraftaki bilgi kullanıcılarının zarar görmesine ve bu durumun bilinçli bir şekilde ortaya çıkmasını hile eylemi olarak ifade edebiliriz. Gerçekleşen her manipülatif işleminde bilgi kullanıcıların zarar görmesi de söylenemez. Kasıt olmaksızın istemeyerek gerçekleşen eylemler ise hata içerinde yer alır. Bir manipülasyon eyleminin hata $\mathrm{m} 1$ yoksa hile mi olduğuna karar vermek konuyu ele alan kişinin bakış açısı ilgilidir (Diana \& Madalina, 2008, s. 939).

İşini doğru şekilde uygulayan kişiler belgeler üzerinde oynama yapmadan, kendi menfaatleri doğrultusunda haksız kazanç elde etme ve zarar verme gibi faaliyet içerisine girmezler. Manipülasyona ortaya çıkarılmasında belge ve kayıtlar en önemli kanıtlayıcı unsur olarak gösterilebilir. Manipülasyon faaliyeti içerisine girmiş bir personel açığa çıkan hilenin tespit edilmesi noktasında agresif ve üzerini örtmeye çalışan birtakım davranışlar içerisinde bulunabilirler (Coenen, 2008, s. 8).

\section{Finansal Bilgi Manipülasyonun Metotları}

Finansal bilgi manipülasyonunu (GKGMİ) "Genel Kabul Görmüş Muhasebe İlkeleri" doğrultusunda, etik kurallara uygun olan ve uygun olmayan metotlar şeklinde iki başlık halinde açılayabiliriz. "Genel Kabul Görmüş Muhasebe İlkeleri'ne" uygun metotlar; kar yönetimi, karın istikrarlı hale getirilmesi, büyük temizlik muhasebesi, agresif muhasebe ve yaratıcı muhasebe olurken, "Genel Kabul Görmüş Muhasebe İlkeleri'ne" aykırı olarak uygulanan manipülasyonları ise, hileli finansal raporlama olarak açıklanmaktadır (Yörük \& Doğan, 2009, s. 68-69).

Kar yönetimi; yöneticiler eliyle yapılan, kısa vadeli dönem karını etkilemeye yönelik faaliyetler şeklinde tanımlanabilir. Kar yönetiminde diğer 
finansal bilgi kullanıcıları ve yatırımcıların düşüncelerini değiştirmek amacı ile ya muhasebe bilgileri yanlış şekilde açıklanır ya da hiç açıklanmaz (Demir \& Bahadır, 2007).

Karın istikrarlı hale getirilmesi, bir işletmenin, kar yönetimi ile raporlanan karlarında oluşan dalgalanmaları ortadan kaldırmak, karı dengeleyerek işletmenin değerinin korunmak amacıyla yürütülen faaliyetler şeklinde tanımlanabilir (Ocak \& Güçlü, 2014, s. 129-130). Karın istikrarlı hale getirilmesi, karın yüksek olduğu dönemlerde karı düşürüp, düşük olduğu dönemlerde de yükselterek istikrarlı bir kar dağıtımı sağlayıp görüntüde daha az riskli bir şirket ortaya çıkarmayı amaçlar (Bekçi \& Avşarlıgil, 2011, s. 136).

Büyük temizlik muhasebesi, şirketlerin üst kademelerinde bulunan yöneticilerin değişmesi veya tasfiyeleri halinde, yönetime yeni gelen yöneticilerin görevlerini devraldıklarında geçmişte karı istikrarlı hale getirmek için uygulanan ekonomik faaliyetleri finansal bilgi kaynaklarından çıkartılarak eski yönetimin izlerini yok etmek ve başarısız bir yönetim sergilediklerini göstermek için yapılan faaliyetlerdir. (Stolowy \& Breton, 2000, s. 43).

Agresif Muhasebe, istenilen sonuca ulaşmak amacı ile yürürlükteki mevcut muhasebe standartlarının uygun ya da uygun olmayan yöntemlerinin zorlayıcı ve bilinçli bir şekilde seçilip uygulanması durumudur. Dönem karını olduğundan yüksek göstermek bu manipülasyon türüne örnek olarak gösterilebilir. Agresif muhasebenin en önemli özelliği, mevcut muhasebe standartlarının kuralları zorlanıp, finansal bilgi manipülasyonu yapılıyor olmasıdır (Mulford \& Comiskey, 2002, s. 28).

Hileli finansal raporlama işlemi, finansal raporların temelinde oluşan bilgileri kasıtlı olarak değiştirmek ve tahrip etmek suretiyle, yatırım yapma düşüncesinde olan ilgilileri ve kredi kuruluşlarını yanıltacak şekilde oluşan tabloların hazırlanması ve sunulması şeklinde ifade edilebilir. Bu şekilde etik ilkelerden uzak şekilde hazırlanan tabloların işletme yöneticilerinin üstlenmiş oldukları yerine getiremediklerini dürüst ve adil bir şekilde raporlama sürecinin oluşmasında engel taşıdıklarını göstermektedir (Rezaee, 2002, s. 1-2). Hileli finansal raporların düzenlenmesinde kasıtlı olarak gerçeğe aykırı belge beyanı, sahte fatura düzenlenmesi uydurma kayıt oluşturma gibi finansal kanıtlayıcı belgeler oluşturarak veya üzerinde değiştirme yapılarak gerçekleşebilmektedir. Bu şekilde oluşan belgeler finansal raporların bilgi kalitesini bozmakta ve işletmenin faaliyetleri sonucunda finansal bilgi edinme ihtiyacı duyan kişileri aldatma eğilimi içerisine girmektedir (Canbulut, 2008, s. 95-96).

\section{YARATICI MUHASEBE UYGULAMALARI}

1986 yılında Ian Griffiths'in kaleme aldığı bir kitap ile literatüre giren "Yaratıcı Muhasebe" kavramı "işletmeler kendi karlarını kendileri belirliyor" iddiasıyla gündeme gelmiştir. Kitabın içeriğinde yatırım yapma düşüncesi içerisinde olan kişilere sunulan finansal tabloların değiştirilerek tahrip edildiği, tabloların gerçek dışı rakamlarla aktarıldığ 1 ifade edilmektedir. Bir hile şekli olarak ifade edilen yaratıcı muhasebenin Truva atından sonra görülen en büyük hile şekli olduğu görülmektedir (Jones M. j., 2011, s. 4). 
$\mathrm{Bu}$ kavram genel olarak piyasa faaliyetlerine yön verici aktörler, analistler ve yorumcular tarafından geliştirilmiştir. Belirli kuramlar çerçevesinde yürütülen uygulamalar ile değil tamamen gözlemleme yoluyla bu kavrama dahil olmuşlardır. $\mathrm{Bu}$ gözlemler neticesinde yatırımcıların zihninde oluşan yüksek kar artışları ve menfaat sağlama arzuları onları aldatıcı yöntemlere itmeye teşvik etmiştir (Stolowy \& Breton, 2000, s. 23).

İngilizcedeki "creative accounting" ifadesi Türkçeye yaratıcı muhasebe olarak çevrilmiştir. "Yaratıcı muhasebe oyunları" anlamında da ele alınan bu yöntem, ölçümlerde yapılan seçimler, muhasebedeki kurallar yardımı ile finansal tablolardaki açıklama özelliklerinin sahip olduğu bir takım boşluklardan faydalanılmak suretiyle mevcut hesaplarda manipülasyon yapılması ve böylelikle finansal raporlama sürecinde istenilenlerin ortaya konulması faaliyetleri olarak açıklanabilir (Daştan, 2010, s. 11).

Yaratıc1 muhasebe, yaratıc1 muhasebe uygulamaları kullanılmadan gerçekleşmesi mümkün olmayan bir takım koşullara uyum sağlamak veya finansal tabloları kullananları yanlış yönlendirmek amacıyla muhasebe kurallarının finansal tabloları hazırlayanlar tarafından esnetilmesi işidir. Yaratıcılık ise bu kuralların esnetilmesi esnasında ortaya çıkmaktadır.

Yaratıcı muhasebe gerçekleştirilirken başarılı olunmak isteniyorsa muhasebe kurallarının esnetilmesi oldukça becerikli ellerce yapılmalıdır. Bu süreç o kadar ustaca ortaya konmalıdır ki, bağımsız denetçiler ortaya çıkan finansal tabloların, mevcut finansal sonuçlar ve işletmenin gerçek finansal durumu hakkında doğru ve sağlıklı bir görünüm ortaya koyduklarını kanıtlayabilmelidir (Archer, 1996, s. 55).

(Mulford \& Comiskey, 2002, s. 49); yaratıc1 muhasebe kavramın1, finansal sonuç raporlarını ayarlamak ve bu raporla aracılığıyla algılanacak olan işletme performansını değiştirmek adına mümkün olan tüm kullanılabilir uygulamaları kapsayan geniş bir kavram olarak açıklamışlardır. (Mulford \& Comiskey, 2002, s. 49), hileli finansal raporlama kavramını ise yaratıcı muhasebe kavramının bir parçası olarak ele alırlarken bir noktaya dikkat çekmişlerdir. Mulford ve Comiskey’e göre hileli finansal raporlamanın söz konusu olabilmesi için cezai bir yargılamada iddia edilmiş olması gerekmektedir.

(Jones M. , 2011, s. 5); yaratıcı muhasebeyi, finansal tabloları hazırlayanların lehine, finansal bilgi kullanıcılarının ise aleyhine olacak şekilde hali hazırda mevcut olan düzenleyici sistemin içinde yer alan yasal boşluklardan faydalanmak, böylelikle muhasebenin esnekliklerinden yararlanmak şeklinde tanımlamıştır. Yine Jones (2011a: 9); bir şirketin muhasebe yasaları ya da muhasebe standartları tarafından izin verilmemiş olan muhasebe uygulamalarını kullanmasını finansal tablolarda hile şeklinde tanımlamış, fakat genel olarak bu tür uygulamaların hile olarak nitelendirilebilmesi için mahkemede bu tür uygulamaların hileli olduklarının ortaya konmuş olması gerektiğini de dile getirmiştir.

Yukarıda yapılan açıklamalardan da anlaşılabileceği gibi yaratıcı muhasebe kavramına ilişkin çok çeşitli tanımlar yapıldığı söylenilebilir. Bu 
durumun altında yatan asıl neden "yaratıcı muhasebe", yaratıcı muhasebeyle ilişkili olarak "hile" ve buradan doğan "hileli finansal raporlama" gibi kavramların farklı bakış açıları ile birbirinden farklı olarak yorumlanması şeklinde açıklanabilir. Yaratıcı muhasebeye ilişkin esas bir tanımı ortaya koyabilmek ancak yaratıcı muhasebe kavramı ile ilgili ortaya atılan görüşlerin ortak noktalarını belirleyerek mümkün olabilir. Ancak hangi tanım dikkate alınırsa alınsın, yaratıcı muhasebe uygulamamalarının finansal tablolardaki bilgileri doğruluk ve gerçeklikten uzaklaştırdığı da ortadadır.

Yaratıcı muhasebe uygulamalarında; muhasebe standartlarında, muhasebe kurallarında, genel kabul gören muhasebe ilkelerinde ve yasalarda yer alan boşluklar, belirsizlikler ve esnekliklerden yararlanma durumu söz konusudur. Yaratıcı muhasebeye ilişkin yapılan tanımların bu kadar çeşitlenmesinde ise yaratıcı muhasebe kavramının hile ve hileli finansal raporlama kavramları ile olan ilişkisi etkili olmaktadır. Hile kavramı, yasaların çiğnenmesi, yasalara aykırı hareket edilmesi veya herhangi bir konu ile ilgili mevcut düzenleyici çerçevenin ihlal edilmesi şeklinde gerçekleşen eylemler olarak karşımıza çıkmaktadır (Jones, 2011a: 8). Finansal tablo hilesi ise muhasebe standartlarının, genel kabul gören muhasebe ilkelerinin veya muhasebe yasalarının ihlal edilmesi şeklinde gerçekleşen eylemler olarak tanımlanmaktadır (Jones, 2011a: 9; (Srivastava \& Tandon, 2014, s. 26).

Mulford ve Comiskey (2002) yaratıcı muhasebe uygulamalarının hileyi de kapsayan çok geniş bir kavram olduğuna dikkat çekerken, Jones (2011a) yaratıcı muhasebenin içinde hilenin yer almadığını bundan dolayı da yasa dışı olmadığını dile getirmektedir. Ancak her iki bakış açısına göre de hile ve hileli finansal raporlama kavramlarından söz edebilmek için bahsi geçen hilenin idari, sivil ya da cezai bir yargılama esnasında iddia olarak ortaya konmuş ya da mahkemece ispatlanmış olması gereklidir (Mulford ve Comiskey, 2002: 49; (Jones M. , 2011, s. 9).

Yaratıcı muhasebe kavramı, muhasebe literatüründe de kendine yer bulan "tutarlılık" kavramının aksine, olayların istenildiği gibi gösterilmesi hatta kitabına uydurmak anlamlarına gelir. Başka bir deyişle, finansal bilgilerin genel kabul gören muhasebe ilkelerinin aksine, yöneticilerin menfaatleri ve işletmelerin amaçları doğrultusunda kullanılmasıdır (Hsieh \& Tsai, 2006, s. 64).

Türkçe 'ye "muhasebecilikte el becerisi" şeklinde de çevrilebilecek olan yaratıcı muhasebe kavramı, kozmetik raporlama, defterleri kaynatma, işletmenin vitrinini düzeltme ve muhasebe makyajlaması gibi anlamlarda kullanılmaktadır. Ayrıca bu uygulamaları yapanlar, yatırımcıları ve karar alıcıları menfaatleri doğrultusunda etkilemek amacıyla bir takım stratejiler kullanırlar. Başka bir deyişle, göz boyamaya yarayan bazı faaliyetlere başvururlar. Bu faaliyetler, küçük işletmelerde karın olduğundan daha az gösterilmesi, büyük işletmelerde ise karın olduğundan daha fazla gösterilmesi amacıyla kullanılmaktadır (Stolowy \& Breton, 2000, s. 44).

Yaratıcı muhasebe uygulamalarına ilişkin literatürde yer alan diğer tanımlar Tablo 2'de özet olarak verilmiştir. 
Hakkı Akman \& Ferhat Bitlisli / Finansal Bilgi Manipülasyonu ve Yaratıcı Muhasebeye İlişkin Meslek Mensupları Üzerine Bir Araştırma

Tablo 2:Yaratıcı muhasebe uygulamalarına ilişkin literatürde yer alan diğer tanımlar

\begin{tabular}{ll}
\hline Yazar & Tanımlamalar \\
\hline Smith (1992) & Muhasebenin El Çabukluğu \\
\hline Griffiths (1986) & Bilgilerin Pişirilmesi \\
\hline Jameson (1988) & Manipülasyon, Hileli Finansal Raporlama \\
\hline Mathews ve Perera (1991) & Kayıtlarda Dalavere Yapmak \\
\hline Mathews ve Perera (1991) & Makyajlı Raporlama \\
\hline Mathews ve Perera (1991) & Vitrin Süsleme \\
\hline Bertolus (1988) & Kayıtlarda Hile Yapma Sanatı \\
\hline Lignon (1989) & Kendi Karını Hesaplama Sanatı \\
\hline Gounin (1991) & Bilanço Sunma Sanatı \\
\hline Pourquery (1991) & Fon Biriktirme Sanatı \\
\hline Schilit (2002) & Muhasebe Kurnazlığı \\
\hline Pasqualini ve Castel (1993) & İşletme Amaçları İçin Finansal Yaratıcılık \\
\hline Black, Sellers ve Manly (1998) & Muhasebenin Yönetimi \\
\hline
\end{tabular}

Kaynak: Stolowy ve Breton, 2000: 25 (Akt., Bayırlı, 2006: 64).

Tablo 2 incelendiğinde literatürde yer alan tanımlamalardan yaratıcı muhasebe uygulamalarına ilişkin genel kabul görmüş tek bir tanım olmadığ1 sonucuna ulaşmak mümkündür. Ancak yine aynı tanımlar yardımıyla yaratıcı muhasebe uygulamalarını ifade eden genel bir kapsamın var olduğu ve yaratıcı muhasebe uygulamalarının mevcut muhasebe uygulama ve kurallarının içinde kalmak koşuluyla, bir takım muhasebe alternatiflerinin kullanılması ile işletme faaliyetlerinin doğal bir sonucu şeklinde oluştuğunu söylemenin mümkün olduğu görülmektedir.

Ayrıca bu bakış açısı, yaratıcı muhasebe uygulamalarının ortaya çıkışında iki temel neden olduğuna dikkat çekmektedir. Ortaya çıkış nedenlerinden birincisi, tüm olası durumlara uygulanamayan muhasebe ilkeleridir. İkincisi ise, yöneticilerin muhasebe ilkelerini uygulamada muhasebeleştirme kuralları ile açık bir şekilde belirtilen alanlarda bile, bazı seçimleri istekleri doğrultusunda yapabilme durumuna sahip olmalarıdir.

Bununla birlikte, yaratıcı muhasebe uygulamaları, vergiden kaçmak için yapılan faaliyetler anlamında da ele alınabilir. Bir başka deyişle, muhasebe ilkelerindeki ve vergi kanunlarındaki boşluklar veya esneklikler nedeniyle, işletme amaçları doğrultusunda bir takım muhasebe seçenekleri kullanılabilmektedir. Örneğin Türkiye'de muhasebe ile ilgili uygulamalarda muhasebeye ilişkin veriler genellikle bilgi amaçlı değil, vergi amaçlı kullanılan veriler şeklindedir. Bu nedenle yaratıcı muhasebe uygulamalarının işletmelerin vergi karşılıklarını düşürmek ya da vergiden kaçınmak amacıyla kullanıldı̆̆ını söylemek mümkündür (Yayla, 2006, s. 18); (Daştan, 2010, s. 3).

\section{A. Yaratıcı Muhasebe Uygulamalarının Literatürdeki Gelişimi}

Literatürdeki çalışmalar incelendiğinde yaratıcı muhasebe uygulamaları kavramının, kar yönetimi ve kazanç yönetimi anlamlarında da kullanıldığı görülmektedir. Bu araştırmada ise "yaratıcı muhasebe uygulamaları" ifadesinin kullanılması tercih edilmiştir.

Muhasebe literatüründe eski bir kavram olarak karşımıza çıkan yaratıcı muhasebe uygulamalarının son dönemde muhasebe alanında yapılan araştırmalarda 
daha sıklıkla ele alındığı söylenebilir. ABD ve Avrupa başta olmak üzere tüm dünyayı etkileyen finansal raporlama skandallarıyla birlikte tekrar gündeme gelen yaratıc1 muhasebe uygulamaları kavramı, son yıllarda yabancı literatürde da popüler hale gelmiş, sıkça sözü edilen bir kavram olmakla birlikte Türkiye'deki araştırmalarda henüz yeni ele alınmaya başlanan bir kavram olarak karşımıza çıkmaktadır.

Yaratıcı muhasebe uygulamaları ilk olarak 1970 yılında iflas açılayan işletmeleri ele alan araştırmalarla karşımıza çıkmıştır. Akademik alanda ilk kez (Griffiths, 1986) tarafindan "Yaratıc1 Muhasebe Uygulamaları: Karlarınız İstediğiniz Gibi Nasıl Yönetebilirsiniz" adlı kitapta ele alınmıştır. Bu çalışmada ortaya konulan teorik bilgiler ilerleyen süreçte pratik olarak işletmelerde uygulanmıştır (McBarnet \& Whelan, 1999, s. 4),

(Smith \& Hannah, 1991), "Büyüme için Muhasebe: İşletme Hesaplarından Gizleme ve Soyma" adlı çalışmalarında yaratıcı muhasebe kavramını ele almışlar ve bu literatürde bir dönüm noktası oluşturmuştur. Yazarlar çalışmalarında, örneklem olarak uluslararası menkul kıymet borsalarında işlem gören 200 işletmeyi ele almışlar, örneklemde yer alan bu işletmelerin çoğunlukla yaratıcı muhasebe uygulama tekniklerine başvurduklarını ortaya koymuşlardır (Smith ve Hannah, 1991, s. 7).

(Saltoğlu, 2003), çalışmasında yaratıcı muhasebe uygulamaları ile 2000 yıllarda meydana gelen ve tüm dünyayı etkileyen Enron skandalı arasındaki ilişkiyi araştırmıştır. Bu çalışmada, Enron'un, özel amaçlı işletmeleri kullanarak muhasebe verilerini ve finansal bilgilerini işletme amaçları doğrultusunda nasıl değiştirdiğini ele almış, çalışma sonucunda işletmelerin piyasa değerini yükseltmek ve giderlerini düşürmek için yaratıcı muhasebe uygulamalarından yararlandıklarını ortaya koymuştur.

(Küçüksözen, 2005), hisse senetleri borsada işlem gören işletmelerin yaratıcı muhasebe uygulamalarına başvurup başvurmadıklarını ortaya koymak için, Beneish (1999) modelinden yararlanmıştır. Bu araştırmada, Beneish modelinin dokuz bağımsız değişkeninden altı tanesi kullanılmıştır. Bunlar, Aktif Kalitesi Endeksi (AKE), Brüt Kar Marjı Endeksi (BKM), Stokların Satışlara Oranı (SSE), Ticari Alacaklar Endeksi (TAE), Finansman Giderlerinin Satışlara Oranı (FSE) ve Amortisman Endeksi (AME) şeklindedir. Beneish modeliyle borsada işlem gören 126 işletmeye ait 1998-2002 yılarına ilişkin beş döneminde sırasıyla; 29 (\%23), 43 (\%34), $32(\% 25), 55(\% 44)$ ve 29 (\%23) oranında işletmelerin yaratıcı muhasebe uygulamalarına başvurduğunu ortaya koymuştur. Yaratıcı muhasebe uygulamalarına başvuran işletmelerin genellikle karı yüksek göstermek amacıyla, yanıltıcı açıklamalar yaptı̆̆ını belirlemiştir.

(Bayırlı, 2006), çalışmasında yaratıcı muhasebe uygulamaları ile işletme değeri ve meslek etiği arasındaki etkileri araştırmıştır. Bu çalışmada, yaratıcı muhasebenin yaygınlığı, içeriği, motive edici faktörleri, sonuçları ve tercih edilen muhasebe uygulamaları üzerinde durmuştur. Bununla birlikte çalışmasında, muhasebe manipülasyonlarını ve yaratıcı muhasebe uygulamalarını ortaya 
çıkarmak amacıyla bir takım model ve tekniklerden yararlanmıştır. Öte yandan bu çalışma ile yaratıcı muhasebenin etik sınırları ortaya konmaya çalışılmıştır.

(Demir \& Bahadır, 2007), araştırmalarında muhasebe manipülasyonlarını yaratıcı muhasebe uygulamaları da dahil bir takım yöntem ve tekniklerle ele almışlardır. Bu amaç doğrultusunda muhasebe manipülasyonunun muhasebe ilke ve standartlarıyla olan ilişkisini, teorik alt yapısını, toplumsal yönünü, amaçlarını çeşitli yöntem ve teknikler ile açıklamışlardır.

(Ömürgönülşen \& Ömürgönülşen, 2009), Türkiye' de yaşanan İmar bankası skandalı ile yaratıcı muhasebe uygulamalarını değerlendirmiştir. Araştırmada, muhasebe ve bankacılık yasal alt yapısının, denetleme ve düzenleme mekanizmalarının eksik ve yetersiz olduğu sonucuna ulaşmışlardır. Bununla birlikte İmar Bankası'nın sahipleri ve üst düzey yöneticileri ile müşterilerinin kişisel hırslarına ek olarak, yargı mekanizmasındaki yavaşlık, yasal ve etik kuralların yürütülmesinde pratikte yaşanan zorluklar gibi etkenlerin yaratıcı muhasebeyi doğuran önemli unsurlar olduğunu dile getirmişlerdir. (Ömürgönülşen ve Ömürgönülşen, 2009: 671).

(Çıtak, 2009), çalışmasında yaratıcı muhasebe uygulamaları ile finansal raporlama hilelileri arasındaki ilişkiyi hem teorik hem de uygulamalı bir biçimde ele almıştır. Çalışma sonucunda, finansal raporlama ile yaratıcı muhasebe uygulamaları arasında bir fark olmadığı sonucuna ulaşmıştır.

(Dhaoui, 2010), araştırma ve geliştirmenin yerelleştirilmesinde karşılaşılan sorunları ortaya koymayı amaçladığı çalışmasında, yaratıcı muhasebe uygulamaları ile işletme performansları arasındaki ilişkiyi incelemiştir. 2001-2006 yılları arasında ABD'de faaliyet gösteren 160 çok uluslu işletmeyi örneklemine dahil etmiş ve araştırma sonucunda yöneticilerin araştırma ve geliştirmeyi yerelleştirdiklerini bunu da kendi çıkarlarına hizmet etmek ve işletme performansını artırmak için yaptıklarını ortaya koymuştur (Dhaoui, 2010, s. 12).

\section{B. Yaratıcı Muhasebenin Etkileri}

(Jones M. , 2011, s. 479-480) yaratıcı muhasebenin etkilerini k1sa dönemli etkiler ve uzun dönemli etkiler olmak üzere iki şekilde incelemiştir. K1sa dönemli etkiler, çalışanlar, denetçiler, yöneticiler, borç verenler ve yatırımcılar ile ilişkilidir. Muhasebe uygulamalarını kötüye kullanmak suçu ile yargılanan yöneticiler, başta hapis cezası olmak üzere, para cezası ya da servete el konulması gibi cezalarla karşılaşmışlardır. (Jones M. , 2011, s. 483), göre çalışanlar, şirketlerin batması sonucu işlerini kaybeden kişiler olduklarından, genellikle muhasebe skandallarında failden çok kurbandırlar. Bununla birlikte, borç verenler ve zarar gören yatırımcılar bu zararlarını telafi edebilmek adına şirketlere karşı dava açsalar da; genellikle borç verenler ve yatırımcılar finansal skandallar ve usulsüzlükler karşısında kaybeden taraftadirlar (Jones, 2011c: 483).

Jones (2011: 484) uzun dönemli etkileri ise, reaksiyoner düzenlemeler ve kümülatif etki şeklinde ikiye ayırmıştır. Reaksiyoner düzenlemeler, skandallar ortaya çıktıktan sonra muhasebe düzenlemelerine bir takım eleştiriler yöneltilmesiyle birlikte yeni bir muhasebe düzenlemesi, standartı ya da kanununun hayata geçirilmesidir (Jones, 2011: 484). Kümülatif etkide ise düzenlemeler ne 
kadar ayrıntılı olursa olsun; hayata geçirilen her yeni düzenlemede yaratıcı muhasebeden yararlanmak isteyenler bir şekilde bu düzenlemeleri bypass edecek yeni bir takım yöntemler geliştireceklerdir. (Jones, 2011: 488). Dolayısıyla yaratıc1 muhasebe ve düzenleyici çerçeve sürekli birbiri ardına gelişmeye devam edecektir (Jones, 2011: 488).

\section{METODOLOJI VE BULGULAR}

\section{A. Araştırmanın Metodolojisi}

Araştırmanın ana kütlesini Isparta ve Burdur İllerinde faaliyet gösteren Serbest Muhasebeci ve Mali Müşavirler oluşturmaktadır. Isparta ve Burdur İllerinde faaliyet gösteren 175 muhasebe meslek mensubuna anket sorular1 yöneltilmiştir.

Araştırmanın amacına hizmet edecek verilerin toplanması amacı ile uygulanan anket üç bölümden oluşmaktadır. Anketin birinci bölümünde katılımcıların demografik bilgilerine ilişkin ifadeler yer almaktadır. Anketin ikinci bölümünde meslek mensuplarının yaratıcı muhasebe hakkında bilgi düzeyleri ve farkındalıklarını ölçmeye yönelik ifadeler yer almaktadır. Anketin üçüncü bölümünde ise (Çelik 2010) tarafindan geliştirilen hile belirteçlerine ilişkin ifadelerin yer aldığı 5'li likert tipi anket uygulanmıştır.

Araştırma kapsamında elde edilen veriler istatistikî analiz paket programı ile değerlendirilmiştir. Analiz öncesinde veriler kodlanmış ve istatistiksel analize hazır hale getirilmiştir. Bu noktada demografik bilgileri ilişkin temel istatistiki bilgilere yer verilmiştir. Meslek mensuplarının yaratıcı muhasebe konusundaki bilgi düzeylerini ölçmeye yönelik ifadelere vermiş oldukları cevaplara frekans analizine tabi tutulmuştur. Muhasebe meslek mensuplarının muhasebede hile belirteçleriyle karşılaşma sıklıklarına ilişkin vermiş oldukları cevapların ortalaması ile muhasebe meslek mensuplarının cinsiyetleri, yaşları, eğitim durumları ve meslek mensubu olarak çalışma süreleri gibi özellikleri açısından, farklılığın olup olmadığını belirlemek amacıyla oluşturulan hipotezlerin test edilmesi amacıyla ttesti (Independent-Samples T Test) ve tek yönlü varyans (One-Way ANOVA) testi yapılmıştır.

Araştırmanın amacına bağlı olarak test edilecek hipotezler aşağıdaki gibi belirlenmiştir;

H1: Muhasebe meslek mensuplarının faaliyet gösterdiği şehre göre muhasebe hile belirteçleriyle karşılaşma sıklıkları arasında fark vardır.

$\mathrm{H} 2$ : Muhasebe meslek mensuplarının cinsiyetlerine göre muhasebe hile belirteçleriyle karşılaşma sıklıkları arasında fark vardır.

H3: Muhasebe meslek mensuplarının yaşlarına göre muhasebe hile belirteçleriyle karşılaşma sıklıkları arasında fark vardır.

H4: Muhasebe meslek mensuplarının eğitim düzeylerine göre muhasebe hile belirteçleriyle karşılaşma sıklıkları arasında fark vardır.

H5: Muhasebe meslek mensuplarının çalışma sürelerine göre muhasebede hile belirteçleriyle karşılaşma sıklıkları arasında fark vardır.

H6: Muhasebe meslek mükellef sayılarına göre muhasebede hile belirteçleriyle karşılaşma sıklıkları arasında fark vardır. 
Hakkı Akman \& Ferhat Bitlisli / Finansal Bilgi Manipülasyonu ve Yaratıcı Muhasebeye İlişkin Meslek Mensupları Üzerine Bir Araştırma

\section{B. Araştırmanın Bulguları}

Araştırmaya katılan meslek mensuplarının şehir, cinsiyet, yaş, eğitim durumu, mesleki tecrübe ve mükellef sayılarına ilişkin demografik özellikleri Tablo 3'de yer almaktadır.

Tablo 3. Araştırmaya katılan meslek mensuplarının Demografik Özellikler

\begin{tabular}{|c|c|c|c|c|}
\hline \multicolumn{2}{|c|}{ Demografik Bilgiler } & \multirow{2}{*}{$\begin{array}{l}\text { Frekans } \\
112\end{array}$} & \multirow{2}{*}{$\begin{array}{l}\text { Yüzde } \\
64\end{array}$} & \multirow{2}{*}{$\begin{array}{l}\text { Toplam Yüzde } \\
64 \\
\end{array}$} \\
\hline & Isparta & & & \\
\hline Şehir & Burdur & 63 & 36 & 100 \\
\hline \multirow{2}{*}{ Cinsiyet } & Kadın & 42 & 24 & 24 \\
\hline & Erkek & 133 & 76 & 100 \\
\hline \multirow{4}{*}{ Yaş } & 26-35 Yaş & 28 & 16 & 16 \\
\hline & $36-45$ Yaş & 56 & 32 & 48 \\
\hline & 46-55 Yaş & 49 & 28 & 76 \\
\hline & 56 Yaș ve Üzeri & 42 & 24 & 100 \\
\hline \multirow{4}{*}{ Eğitim Düzeyi } & Ortaöğretim & 35 & 20 & 20 \\
\hline & Ön Lisans & 7 & 4 & 24 \\
\hline & Lisans & 115 & 66 & 90 \\
\hline & Lisansüstü & 18 & 10 & 100 \\
\hline \multirow{4}{*}{ Mesleki Tecrübe } & $0-5$ Yil & 21 & 12 & 12 \\
\hline & $5-10 Y_{11}$ & 53 & 30 & 42 \\
\hline & 10-15 Y1l & 42 & 25 & 67 \\
\hline & 15 Y1l Üstü & 59 & 33 & 100 \\
\hline \multirow{5}{*}{ Mükellef Sayısı } & 30 ve Altı & 14 & 8 & 8 \\
\hline & $31-60$ & 77 & 44 & 52 \\
\hline & $61-90$ & 49 & 28 & 80 \\
\hline & $91-120$ & 28 & 16 & 96 \\
\hline & 120 Ve Üstü & 7 & 4 & 100 \\
\hline
\end{tabular}

Muhasebe meslek mensuplarının yaratıcı muhasebe uygulamalarına ilişkin ifadelere vermiş oldukları cevapların frekans analizi sonuçları Tablo 3'deki gibidir.

Tablo 4. Yaratıcı Muhasebe Uygulamalarına Yönelik Bulgular

\begin{tabular}{|c|c|c|c|c|}
\hline & & Frekans & Yüzde & $\begin{array}{l}\text { Toplam } \\
\text { Yüzde }\end{array}$ \\
\hline \multirow{5}{*}{$\begin{array}{l}\text { Yaratıcı Muhasebe Uygulamaları hakkında ne kadar } \\
\text { bilgili olduğunuzu düşünüyorsunuz? }\end{array}$} & Hiç & 0 & 58,9 & 58,9 \\
\hline & Çok Az & 16 & 9,1 & 68 \\
\hline & Orta & 13 & 7,4 & 75,4 \\
\hline & Oldukça & 30 & 17,1 & 92,5 \\
\hline & Çok fazla & 13 & 7,5 & 100 \\
\hline \multirow{5}{*}{$\begin{array}{l}\text { Sizce yaratıcı muhasebe uygulamalarına başvurmak } \\
\text { istenilmesinin işletmeye ne gibi bir etkisi olur? }\end{array}$} & İssletmeyi Daha İyi Gösterme & 6 & 3,5 & 3,5 \\
\hline & İşletmeyi Daha Kötü Gösterme & 5 & 2,9 & 6,4 \\
\hline & Daha Az Vergi Ödemek & 140 & 81 & 87,4 \\
\hline & Daha Az Kar Payı Dağıtmak & 15 & 8,6 & 96 \\
\hline & Hisse Fiyatı Arttırmak & 7 & 4 & 100 \\
\hline \multirow{2}{*}{$\begin{array}{l}\text { Müşterileriniz tarafindan Yaratıcı Muhasebe } \\
\text { Uygulamaları olarak tanımlanabilecek işlemleri } \\
\text { yapmanız istendi mi? }\end{array}$} & Evet & 42 & 24 & 24 \\
\hline & Hayır & 133 & 76 & 100 \\
\hline \multirow{5}{*}{ Muhasebe hataları hakkında bilginiz var mı? } & Hiç & 13 & 7,4 & 7,4 \\
\hline & Çok Az & 6 & 3,4 & 10,8 \\
\hline & Orta & 56 & 32 & 42,8 \\
\hline & Oldukça & 74 & 42,3 & 85,1 \\
\hline & Oldukça Fazla & 26 & 14,9 & 100 \\
\hline Muhasebe hileleri hakkında bilginiz var mı? & Hiç & 0 & 0 & 0 \\
\hline
\end{tabular}




\begin{tabular}{|c|c|c|c|c|}
\hline & Çok Az & 3 & 1,7 & 1,7 \\
\hline & Orta & 63 & 36 & 37,7 \\
\hline & Oldukça & 84 & 48 & 85,7 \\
\hline & Oldukça Fazla & 25 & 14,3 & 100 \\
\hline \multirow{4}{*}{$\begin{array}{l}\text { Sizce muhasebede yapılan hataların en önemli nedeni } \\
\text { nedir? }\end{array}$} & Bilgisizlik & 21 & 12 & 12 \\
\hline & Dikkatsizlik & 63 & 36 & 48 \\
\hline & İş Yoğunluğu & 49 & 28 & 76 \\
\hline & Tecrübesizlik & 42 & 24 & 100 \\
\hline \multirow{4}{*}{$\begin{array}{l}\text { Sizce muhasebede yapılan hilelerin en önemli nedeni } \\
\text { nedir? }\end{array}$} & Karı Artırmak & 21 & 12 & 12 \\
\hline & Vergi Matrahını Düşürmek & 98 & 56 & 68 \\
\hline & İşletme Değerini Arttırmak & 7 & 4 & 72 \\
\hline & Art Niyetli Olmak & 49 & 28 & 100 \\
\hline \multirow{2}{*}{$\begin{array}{l}\text { Müşterileriniz tarafından hiç Genel Kabul Görmüş } \\
\text { Muhasebe İlkelerine aykırı davranmanız istendi mi? }\end{array}$} & Evet & 140 & 80 & 80 \\
\hline & Hayır & 35 & 20 & 100 \\
\hline \multirow{2}{*}{$\begin{array}{l}\text { Müşterileriniz tarafından işletmenin faaliyet } \\
\text { sonuçlarını olumlu ya da olumsuz yönde } \\
\text { değiştirmeniz istendi mi? }\end{array}$} & Evet & 161 & 92 & 92 \\
\hline & Hayır & 14 & 8 & 100 \\
\hline \multirow{2}{*}{$\begin{array}{l}\text { Müşterileriniz tarafindan işletmenin finansal } \\
\text { raporlarını olumlu ya da olumsuz yönde } \\
\text { değiştirmeniz istendi mi? }\end{array}$} & Evet & 147 & 84 & 84 \\
\hline & Hayır & 28 & 16 & 100 \\
\hline \multirow{5}{*}{$\begin{array}{l}\text { Yaratıcı Muhasebe Uygulamalarıyla, finansal } \\
\text { raporların daha iyi gösterilmesinin işletmeye katkısı } \\
\text { ne olabilir? }\end{array}$} & İşletme İmajını Güçlendirmek & 23 & 13,00 & 13 \\
\hline & Yatırımcı Çekmek & 22 & 13,00 & 26 \\
\hline & Kredi Alabilmek & 115 & 66,00 & 92 \\
\hline & Yük Prim ve İkramiye Dağıtmak & 10 & 5,00 & 97 \\
\hline & İşletmenin Borsa Değerini Arttırmak & 5 & 3,00 & 100 \\
\hline \multirow{2}{*}{$\begin{array}{l}\text { Müşterileriniz arasında bağımsız dış denetim yaptıran } \\
\text { işletme var mı? }\end{array}$} & Evet & 42 & 24 & 24 \\
\hline & Hayır & 133 & 76 & 100 \\
\hline \multirow{5}{*}{$\begin{array}{l}\text { Bir işletmeye ait mali tabloları incelerken dipnotları } \\
\text { ne derece dikkate alırsınız? }\end{array}$} & Hiç & 77 & 44,00 & 44 \\
\hline & Nadiren & 42 & 24,00 & 68 \\
\hline & Bazen & 11 & 6,30 & 74,3 \\
\hline & S1klikla & 35 & 20,00 & 94,3 \\
\hline & Her zaman & 10 & 5,70 & 100 \\
\hline \multirow{5}{*}{$\begin{array}{l}\text { Bir işletmeye ait hisse senetlerini satın almayı } \\
\text { düşündügünüzde denetlenmiş finansal raporlar } \\
\text { önceden hangi sıklıkla incelersiniz? }\end{array}$} & Hiç & 63 & 36,00 & 36 \\
\hline & Nadiren & 77 & 44,00 & 80 \\
\hline & Bazen & 19 & 10,90 & 90,9 \\
\hline & S1klıkla & 7 & 4,00 & 94,9 \\
\hline & Her zaman & 9 & 5,10 & 100 \\
\hline
\end{tabular}

Muhasebe meslek mensuplarının \%58,9'nun yaratıc1 muhasebe uygulamaları hakkında bilgi sahibi olmadıkları ve \% 81 gibi büyük çoğunluğunun yaratıcı muhasebe uygulamalarına başvurulmasının işletmenin vergi yükünü düşürmek amacına yönelik olduğunu ifade ettikleri tespit edilmiştir. Yine \% 76 gibi büyük bir çoğunluğunun mükellefleri tarafindan yaratıcı muhasebe uygulamalarına yönelik taleplerinin olmadığı görülmektedir. Meslek mensuplarının büyük bir çoğunluğunun muhasebe hataları ve muhasebe hileleri konusunda oldukça bilgisi olduğu ve çok fazla bilgisi olduğu bildiriminde bulunduğu tespit edilmiştir. Muhasebeleştirmeye ilişkin yapılan hataların nedenlerinin tespitine yönelik olarak yöneltilen ifadeye meslek mensuplarının \% 36 's1 dikkatsizlik, \% 28'i iş yoğunluğu, \% 24'ü tecrübesizlik ve \% 21'i bilgisizlik şeklinde cevap verdikleri görülmüştür. Muhasebe hilelerinin sebebinin tespitine yönelik olarak yöneltilen ifadeye ise meslek mensuplarının \% 56'sı vergi matrahını 
düşürmek şeklinde cevap verdikleri tespit edilmiştir. Katılımcıların \% 80 gibi büyük bir çoğunluğunun mükellefleri tarafından genel kabul görmüş muhasebe ilkelerine aykırı davranmaları konusunda talepte bulunduğunu, yine \% 92'i gibi büyük çoğunluğunun faaliyet sonuçlarını değiştirme talebinde bulunduğunu, \% 84'nün ise finansal raporların değiştirilmesi konusunda talepte bulunduğunu ifade etmişlerdir. Yaratıcı muhasebe uygulamaları ile finansal raporların daha iyi gösterilmesinin işletme katkısının kredi almaya yönelik (\% 66) olacağını ifade etmişlerdir. Muhasebe meslek mensuplarının mükelleflerinin \% 66'sının bağımsız denetime tabi olmadığı veya bağımsız denetim yaptırmadığı tespit edilmiştir. Muhasebe meslek mensuplarının \% 68 gibi büyük çoğunluğunun bilanço dipnotları hiç veya nadiren dikkate aldıkları görülmektedir. Yine meslek mensuplarının \% 80 gibi büyük bir çoğunluğunun hisse senedi satın almayı düşünmeleri halinde denetlenmiş finansal tabloları incelemeyecekleri bildiriminde bulundukları görülmektedir.

Araştırmaya katılan meslek mensuplarına (Çelik, 2010) tarafından muhasebede hata ve hileler ile ilgili geliştirilen hile belirteçlerini tespit etmeye yönelik 5'li likert tipi anket uygulanmış, meslek mensuplarının "hile belirteçleri ile karşılaşma sıklıkları" hususunda kendilerine yöneltilen maddelere vermiş oldukları cevapların puan ortalamaları belirlenmiştir. Ankete katılan 175 meslek mensubundan cevapları aykırı-uç değerler oluşturan 7 kişinin yanıtları veri setinden çıkartılmış, kalan 168 kişiye ait oluşan puan ortalamaları üzerinde normallik testi uygulanmıştır. Veri setinin normallik testi sonuçları Tablo 5'de paylaşılmıştır.

Tablo 5. Normallik Testi Sonuçları

\begin{tabular}{|c|c|c|c|c|c|c|}
\hline & \multicolumn{3}{|c|}{ Kolmogorov-Smirnov(a) } & \multicolumn{3}{|c|}{ Shapiro-Wilk } \\
\hline & İstatistik & $\mathrm{Sd}$ & p. & İstatistik & $\mathrm{Sd}$ & p. \\
\hline Puan Ortalamaları & .049 & 168 & $.200(*)$ & .989 & 168 & .209 \\
\hline
\end{tabular}

Çalışmada 5'li likert tipi veri toplama aracı ile elde edilen "hile belirteçleri ile karşılaşma sıklığı” puan ortalamaları 1 ile 5 arasındaki değerlerden oluştuğundan dolayı, istatistiksel analizler sonucunda elde edilen ortalamaların yorumlanmasında göz önünde bulundurulan puan aralıkları Tablo 6'de verilmiştir.

Tablo 6. Ortalama puanlara göre karşılaşma sıklık dereceleri

\begin{tabular}{ll}
\hline Oluşan Puan Ortalaması & YMU ile karşılaşma Sıklığı Derecesi \\
\hline $1.00-1,80$ & Düşük Sıklı̈ \\
$1,81-2,60$ & Düşük-Orta Sıklık \\
$2,61-3,40$ & Orta Sıklık \\
$3,41-4,20$ & Yüksek-Orta Sıklık \\
$4,21-5,00$ & Yüksek Sıklık \\
\hline
\end{tabular}

Normal dağılım gösterdiği $(p=.200>.05)$ belirlenen puan ortalamaları, meslek mensuplarının yaşadıkları şehir ve cinsiyetleri açısından karşılaştırıldı̆̆ında gruplar arasında istatistiksel açıdan anlamlı bir fark oluşup oluşmadığını sorgulamak adına bağımsız örneklem t-testinden yararlanılmış, test sonuçları Tablo 7'te sunulmuştur. 
Tablo 7. Şehir ve cinsiyet değişkenlerine ilişkin bağımsız örneklem t-testi sonuçları

\begin{tabular}{lllllll}
\hline & \multicolumn{3}{c}{ Grup İstatistikleri } & \multicolumn{3}{c}{ Bağımsız Örneklem t-Testi } \\
\hline & Grup & $\mathrm{N}$ & Ortalama & Standart Sapma & $\mathrm{T}$ & $\mathrm{P}$ \\
\hline \multirow{2}{*}{ Şehir } & Isparta & 112 & 3,94 &, 394 &, 267 &, 790 \\
& Burdur & 56 & 3,92 &, 437 &, 258 & \\
\hline \multirow{2}{*}{ Cinsiyet } & Erkek & 133 & 3,95 &, 435 & 1,048 & \multirow{2}{*}{, 181} \\
& Kadın & 35 & 3,87 &, 277 & 1,348 & \\
\hline
\end{tabular}

Isparta'da yaşayan meslek mensuplarının hile belirteçleri ile karşılaşma sıklığg puan ortalamaları 3,94 olurken, Burdur'da yaşayan meslek mensupları için bu puan 3,92 olarak belirlenmiştir. İki grubun puan ortalamaları birbirine oldukça yakındır ve yüksek-orta karşılaşma sıklığını işaret etmektedir. Benzer şekilde erkek meslek mensuplarının puan ortalamaları $(3,95)$ ile kadın meslek mensuplarının puan ortalamaları $(3,87)$ da birbirine çok yakındır. Her iki grubun da hile belirteçleri ile karşılaşma sıklıkları yüksek-orta olarak belirlenmiştir. Bağımsız örneklem t-testi sonuçlarına göre muhasebe meslek mensuplarının yaşadıkları şehirlerin $(p=.790>.05)$ ve cinsiyetlerinin $(p=.181>.05)$ hile belirteçleri ile karşılaşma sıklıkları üzerinde herhangi bir farklılığa neden olmadığı söylenebilir.

Meslek mensuplarının eğitim düzeyleri, yaşları, mesleki tecrübe yılları ve mükellef sayıları ile yaratıcı muhasebe uygulamaları ile karşılaşma sıklıkları arasında farklılaşma durumlarını test edebilmek için ise veri seti üzerinde tek yönlü varyans analizi (ANOVA) uygulanmıştır ve sonuçlar Tablo 8'de verilmiştir.

Tablo 8. Bağımsız değişkenlere yönelik varyans analizi sonuçları

\begin{tabular}{|c|c|c|c|c|c|c|}
\hline & Gruplar & $\mathrm{N}$ & Ortalama & Standart Sapma & $\mathrm{F}$ & $\mathrm{p}$ \\
\hline \multirow[t]{4}{*}{ Eğitim Düzeyi } & Ortaöğretim & 35 & 3,87 & 0,277 & \multirow[t]{4}{*}{10,934} & \multirow[t]{4}{*}{, 000} \\
\hline & Ön lisans & 7 & 4,52 & 0,129 & & \\
\hline & Lisans & 108 & 3,97 & 0,372 & & \\
\hline & Yüksek Lisans & 18 & 3,60 & 0,574 & & \\
\hline \multirow[t]{4}{*}{ Yaş } & $26-35$ yaş & 21 & 3,70 & 0,524 & \multirow[t]{4}{*}{4,009} & \multirow[t]{4}{*}{,009 } \\
\hline & $36-45$ yaş & 56 & 3,90 & 0,360 & & \\
\hline & $46-55$ yaş & 49 & 4,05 & 0,385 & & \\
\hline & 56 yaş ve üzeri & 42 & 3,95 & 0,386 & & \\
\hline \multirow[t]{4}{*}{ Meslek Y1l } & $0-5$ y1l & 21 & 3,73 & 0,531 & \multirow[t]{4}{*}{5,651} & \multirow[t]{4}{*}{,001 } \\
\hline & $5-10$ y1l & 49 & 3,81 & 0,297 & & \\
\hline & $10-15$ y1l & 42 & 4,03 & 0,454 & & \\
\hline & 15 yıl ve üzeri & 56 & 4,04 & 0,352 & & \\
\hline \multirow[t]{5}{*}{ Mükellef Sayısı } & 30 ve altı & 7 & 4,55 & 0,225 & \multirow[t]{5}{*}{8,454} & \multirow[t]{5}{*}{,000 } \\
\hline & $31-60$ & 77 & 3,98 & 0,382 & & \\
\hline & $61-90$ & 49 & 3,74 & 0,349 & & \\
\hline & $91-120$ & 28 & 4,00 & 0,456 & & \\
\hline & 120 ve üzeri & 7 & 3,92 & 0,133 & & \\
\hline
\end{tabular}

Tablo 8. değerlendirildiğinde varyans analizi sonuçlarına göre hile belirteçleri karşılaşma sıklıkları ile meslek mensuplarının eğitim düzeyleri, yaşları, mesleki tecrübe yılları ve sahip oldukları mükellef sayıları bağımsız değişkenlerinin tamamı arasında istatistiksel açıdan anlamlı farklılaşmalar olduğu sonucuna ulaşılmıştır $(\mathrm{p}<, 05)$. Bu farklılaşmanın hangi gruplar arasında oluştuğunu belirleyebilmek adına çoklu karşılaştırmalar tabloları hazırlanmış ve bağımsız değişkenleri temsil eden gruplar karşılaştırılmıştır. 
Tablo 9. Eğitim düzeyi değişkenine yönelik çoklu karşılaştırmalar

\begin{tabular}{|c|c|c|c|c|}
\hline Bağımsız Değişken & (I) Grup & (J) Grup & Ort. Fark (I-J) & $\mathrm{P}$ \\
\hline \multirow{12}{*}{ Eğitim Düzeyi } & \multirow[t]{3}{*}{ Ortaöğretim } & Ön lisans &,$- 647(*)$ & 000 \\
\hline & & Lisans &,- 093 &, 577 \\
\hline & & Yüksek lisans &, 270 & ,066 \\
\hline & \multirow[t]{3}{*}{ Ön lisans } & Ortaöğretim & ,647(*) &, 000 \\
\hline & & Lisans &, $553(*)$ & ,001 \\
\hline & & Yüksek lisans &, $917(*)$ & ,000 \\
\hline & \multirow[t]{3}{*}{ Lisans } & Ortaöğretim & ,093 &, 577 \\
\hline & & Ön lisans &,$- 553(*)$ & ,001 \\
\hline & & Yüksek lisans &, $364(*)$ & ,001 \\
\hline & \multirow[t]{3}{*}{ Yüksek Lisans } & Ortaöğretim &,- 270 &, 066 \\
\hline & & Ön lisans &,$- 917(*)$ & ,000 \\
\hline & & Lisans &,$- 364(*)$ & 001 \\
\hline
\end{tabular}

bulundurulduğunda yaratıcı muhasebe uygulamaları ile karşılaşma sıklıkları en yüksek olan eğitim düzeyi grubunun 4,52 ortalama ile ön lisans mezunları, en düşük olan grubun ise 3,60 ortalama puan ile yüksek lisans mezunları olduğu görülmüştür (Tablo 8.). Bununla birlikte, hile belirteçleri ile karşılaşma sıklığ 1 puanı en yüksek olan (yüksek karşılaşma sıklığı) ön lisans mezunları ile ortalama puanları yüksekorta karşılaşma sıklığına denk olan diğer gruplar (ortaöğretim, lisans ve yüksek lisans mezunları) arasında oluşan farkın istatistiksel olarak anlamlı olduğu sonucuna ulaşılmıștır (Tablo 9).

Tablo 10. Yaş değişkenine yönelik çoklu karşılaştırmalar

\begin{tabular}{|c|c|c|c|c|}
\hline Bağımsız Değişken & (I) Grup & (J) Grup & Ort. Fark (I-J) & $\mathrm{p}$ \\
\hline \multirow{12}{*}{ Yaş } & \multirow[t]{3}{*}{ 26-35 yaş } & 36-45 yaş &,- 191 & 239 \\
\hline & & $46-55$ yaş &,$- 348(*)$ & 005 \\
\hline & & 56 ve üzeri yaş &,- 248 & ,093 \\
\hline & \multirow[t]{3}{*}{ 36-45 yaş } & $26-35$ yaş &, 191 & ,239 \\
\hline & & $46-55$ yaş &,- 157 & , 184 \\
\hline & & 56 ve üzeri yaş &,- 057 &, 896 \\
\hline & \multirow[t]{3}{*}{$46-55$ yaş } & $26-35$ yaş & ,348(*) &, 005 \\
\hline & & $36-45$ yaş &, 157 & 184 \\
\hline & & 56 ve üzeri yaş &, 100 & ,628 \\
\hline & \multirow[t]{3}{*}{56 ve üzeri yaş } & $26-35$ yaş & ,248 & ,093 \\
\hline & & $36-45$ yaş &, 057 & ,896 \\
\hline & & $46-55$ yaş &,- 100 &, 628 \\
\hline
\end{tabular}

Bağımsız değişken olarak meslek mensuplarının yaşları ele alındığında hile belirteçleri ile en sık karşılaşan meslek mensuplarının 4,05 ortalama puan ile 46-55 yaş grubunda olduğu sonucuna ulaşılmıştır. Bu grubu sırasıyla; 56 yaş ve üzeri (3,95 ortalama puan), 36-45 yaş (3,90 ortalama puan) ve $26-35$ yaş grubunun $(3,70$ ortalama puan) görülmüştür (Tablo 8). Bu sonuç 26-35 yaş aralığındaki meslek mensuplarının diğer meslektaşlarına göre hile belirteçleri ile daha az sıklıkla karşılaştığ 1 şeklinde yorumlanabilir. Aynı zamanda 26-35 yaş grubu ile 46-55 yaş grubunun puan ortalamaları arasındaki fark istatistiksel açıdan anlamlıdır (Tablo 10.). Tüm gruplar için ortalamalar yüksek-orta karşılaşma sıklığını ifade etmektedir. 
Tablo 11. Mesleki tecrübe yılı değişkenine yönelik çoklu karşı̧laştırmalar

\begin{tabular}{|c|c|c|c|c|}
\hline Bağımsız Değişken & (I) Grup & (J) Grup & Ort. Fark (I-J) & $\mathrm{P}$ \\
\hline \multirow{12}{*}{ Mesleki Y1lı } & \multirow[t]{3}{*}{$0-5$ y1l } & $5-10$ y1l &,- 074 & 886 \\
\hline & & $10-15$ y1l &,$- 299(*)$ & 024 \\
\hline & & 15 yıl ve üzeri &,$- 301(*)$ & 016 \\
\hline & \multirow[t]{3}{*}{$5-10$ y1l } & $0-5$ y1l & ,074 & ,886 \\
\hline & & $10-15$ y1l &,$- 225(*)$ & 035 \\
\hline & & 15 yıl ve üzeri &,$- 227(*)$ & 018 \\
\hline & \multirow[t]{3}{*}{$10-15$ y1l } & $0-5$ y1l & ,299(*) &, 024 \\
\hline & & $5-10$ y1l & ,225(*) & 035 \\
\hline & & 15 yıl ve üzeri &,- 002 & 1,000 \\
\hline & \multirow[t]{3}{*}{15 y1l ve üzeri } & $0-5$ y1l & ,301(*) & ,016 \\
\hline & & $5-10$ y1l & $227(*)$ & 018 \\
\hline & & $10-15$ y1l &, 002 & 1,000 \\
\hline
\end{tabular}

Bağımsız değişkenlerden meslek yılı değerlendirildiğinde hile belirteçleri ile karşılaşma sıklığı puanlarının gruplara göre sırasıyla $0-5$ y1l için 3,73; 5-10 y1l için 3,$81 ; 10-15$ yıl için 4,03 ve 15 y1l üzeri için 4,04 şeklinde oluştuğu sonucuna varılmıştır (Tablo 8.). Bu sonuç kişilerin mesleki tecrübeleri bir başka deyişle meslekte geçirdikleri süreleri arttıkça yaratıcı muhasebe uygulamaları ile karşılaşma sıklıklarının da artıyor olduğu şeklinde yorumlanabilir. Bununla birlikte 0-5 yıl ve 5-10 yıl mesleki tecrübeye sahip grupların ortalamaları arasındaki fark istatistiksel açıdan anlamlı değilken, her iki grubun da $10-15$ yıl ve 15 y1l üzeri mesleki tecrübeye sahip gruplarla aralarında oluşan puan ortalamaları farklarının istatistiksel açıdan anlamlı olduğu sonucuna ulaşılmıştır (Tablo 7.). Tüm gruplar için oluşan ortalama puanlar yaratıcı hile belirteçleri ile yüksek-orta sıklıkla karş1laşma durumunu göstermektedir.

Tablo 12. Mükellef sayısı değişkenine yönelik çoklu karşılaştırmalar

\begin{tabular}{|c|c|c|c|c|}
\hline Bağımsız Değișken & (I) Grup & (J) Grup & Ort. Fark (I-J) & $\mathrm{P}$ \\
\hline \multirow{20}{*}{ Mükellef Sayısı } & \multirow[t]{4}{*}{30 ve alt1 } & $31-60$ &, $574(*)$ & 001 \\
\hline & & $61-90$ &, $812(*)$ &, 000 \\
\hline & & $91-120$ &, $559(*)$ & ,005 \\
\hline & & 120 ve üzeri & ,633(*) &, 016 \\
\hline & \multirow[t]{4}{*}{$31-60$} & 30 ve altı &,$- 574(*)$ & 001 \\
\hline & & $61-90$ & ,238(*) & ,006 \\
\hline & & $91-120$ &,- 016 & 1,000 \\
\hline & & 120 ve üzeri &, 058 & ,995 \\
\hline & \multirow[t]{4}{*}{$61-90$} & 30 ve altı &,$- 812(*)$ & ,000 \\
\hline & & $31-60$ &,$- 237(*)$ & ,006 \\
\hline & & $91-120$ &,$- 253(*)$ & 039 \\
\hline & & 120 ve üzeri &,- 179 & ,762 \\
\hline & \multirow[t]{4}{*}{$91-120$} & 30 ve altı &,$- 559(*)$ &, 005 \\
\hline & & $31-60$ &, 016 & 1,000 \\
\hline & & $61-90$ & ,253(*) &, 039 \\
\hline & & 120 ve üzeri &, 074 & 990 \\
\hline & \multirow[t]{4}{*}{120 ve üzeri } & 30 ve altı &,$- 633(*)$ & ,016 \\
\hline & & $31-60$ &,- 058 & ,995 \\
\hline & & $61-90$ &, 179 &, 762 \\
\hline & & $91-120$ &,- 074 & ,990 \\
\hline
\end{tabular}

Bir başka bağımsız değişken olarak meslek mensuplarının sahip oldukları mükellef sayıları göz önünde bulundurulduğunda, hile belirteçleri ile karşılaşma sıklık puanı en yüksek kişilerin 30 ve altında mükellef sayısına sahip grup olduğu (4,55 ortalama puan) ve elde edilen puan ortalamasının yüksek sıklığa karşılık geldiği görülmüştür (Tablo 8). Bu grubun diğer tüm gruplar ile arasında oluşan 
puan farkları istatistiksel açıdan anlamlıdır (Tablo 12). Bu grubu sırasıyla; 91-120 mükellef sahibi (4,00 ortalama puan), 31-60 mükellef sahibi (3,98 ortalama puan), 120 ve üzeri mükellef sahibi (3,92 ortalama puan) meslek mensupları izlemektedir ve grupların tamamının puan ortalamaları hile belirteçleri ile yüksek-orta sıklıkla karşılaşma durumunu ifade etmektedir. (Tablo 8). Bu 3 grup arasında oluşan puan ortalama farklarının ise istatistiksel açıdan anlamlı olmadığı sonucuna ulaşılmıştır (Tablo 8.). Bununla birlikte yaratıcı muhasebe uygulamaları ile karşılaşma sıklık puanı en düşük kişilerin 3,74 ortalama puan ile 61-90 mükellef sayısına sahip meslek mensuplarının oluşturduğu grupta oldukları görülmüştür (Tablo 8). Bu grubun 120 ve üzerinde mükellefi olan meslek mensuplarının oluşturduğu grup dışındaki tüm gruplar ile arasında meydana gelen ortalama farkı istatistiksel açıdan anlamlidir (Tablo 12).

\section{SONUÇ}

Yaratıcı muhasebe uygulamaları, muhasebe manipülasyon yöntemlerinden biri olup, muhasebe ilke ve standartlarında var olan esnekliklerden ve boşluklardan yararlanmak sureti ile değişik amaçlarla finansal bilgi ihtiyacı duyan finansal tablo kullanıcılarının kararları üzerinde etkili olmaya çalışmak olarak ifade edilmektedir. İşletmelerin finansal tablo kullanıcılarına sunduğu finansal bilgilerin genel kabul görmüş muhasebe ilkeleri doğrultusunda güvenilir, karş1laştırılabilir, ihtiyaca uygun, anlaşılır, tarafsız, tutarlı, ihtiyatlı ve tam açıklama niteliklerine yer verecek şekilde sunulması finansal tablo kullanıcıları açısından büyük önem arz etmektedir. Finansal bilgi manipülasyonu türlerinden biri olarak ele alınan yaratıcı muhasebe birçok kesimin ilgisini çekmektedir. Bu noktada finansal bilginin oluşmasında ve sunumunda önemli rol oynayan muhasebe meslek mensuplarının bu noktadaki düşüncelerinin ve farkındalıklarının tespiti önem arz etmektedir. Bu amaçla meslek mensuplarının yaratıcı muhasebeye ve hile belirteçleri ile karşılaşma sıklıklarını belirlemeye yönelik olarak yapmış olduğumuz araştırmada elde edilen veriler sonucunda muhasebe meslek mensuplarının büyük çoğunluğunun yaratıcı muhasebe uygulamaları hakkında bilgi sahibi olmadıkları ve mükellefleri tarafından yaratıcı muhasebe uygulamalarına yönelik taleplerinin bulunmadı̆̆ını bu tür taleple karşılaşanların ise; başvurma nedeni olarak vergi yükünü azaltmak amacıyla talep edildiği gözlemlenmiştir. Muhasebe hata ve hileleri ile ilgili bilgi düzeyleri ise; oldukça bilgili seviyededir. Yapılan hataların büyük çoğunluğunun "dikkatsizlik" nedeniyle yapıldığı, hilelerin ise "vergi matrahını" düşürmek amacıyla gerçekleştiği görülmüştür. Meslek mensuplarının mükellefleri tarafından genel kabul görmüş muhasebe ilkelerine aykırı davranmaları konusundaki taleplerin faaliyet sonuçlarını değiştirmeye yönelik olduğu, bu netice doğrultusunda finansal raporların iyi gösterilerek işletmelerin kredi almaya uygun koşulların oluşturulması için yapıldığı gözlemlenmiştir. Mükelleflerin çoğunluğunun bağımsız denetim yaptırmadığı ve bilançoda oluşan dipnotları dikkate almadıkları görülerek; hisse senedi almaları durumunda finansal tablolardan faydalanma gereksinimi duymadıkları ifade edilmiştir.

Isparta ve Burdur illerinde faaliyet gösteren meslek mensuplarının bağımsız örneklem t-testi sonuçlarına göre hile belirteçleriyle karşılaşma durumları 
cinsiyet olarak birbirleriyle yakın orantılıdır. Meslek mensuplarının eğitim düzeyleri, yaşları, mesleki tecrübe yılları ve mükellef sayıları ile yaratıcı muhasebe uygulamaları ile karşılaşma sıklıkları arasında farklılaşma durumlarını test edebilmek için ise veri seti üzerinde tek yönlü varyans analizi (ANOVA) uygulanmıştır. Uygulama neticesinde; istatistiksel açıdan anlamlı farklılaşmalar olduğu sonucuna ulaşılmıştır. Bu farklılaşmalar bağımsız değişkenleri temsil eden gruplar karşılaştııılmıştır. Eğitim düzeyi değişkenine yönelik çoklu karşılaştırmalar sonucuna göre eğitim düzeyleri arasında oluşan farkın istatistiksel olarak anlamlı olduğu gözlemlenmiştir. Bağımsız değişken olarak meslek mensuplarının yaşları ele alındığında hile belirteçleri ile en sık karşılaşan meslek mensuplarının puan ortalamaları arasındaki fark istatistiksel açıdan anlamlıdır. Bağımsız değişkenlerden meslek yılı değerlendirildiğinde ise; hile belirteçleri ile karşılaşma sıklığ 1 aralarında oluşan puan ortalamaları farklarının istatistiksel açıdan anlamlı olduğu sonucuna ulaşılmıştır. Bir başka bağımsız değişken olarak meslek mensuplarının sahip oldukları mükellef sayıları göz önünde bulundurulduğunda, hile belirteçleri ile karşılaşma sıklık puanı bu grubun diğer tüm gruplar ile arasında oluşan puan farkları istatistiksel açıdan anlamlıdır.

\section{Araştırma ve Yayın Etiği Beyanı}

Makalenin tüm süreçlerinde Yönetim ve Ekonomi Dergisi'nin araştırma ve yayın etiği ilkelerine uygun olarak hareket edilmiştir.

\section{Yazarların Makaleye Katkı Oranları}

Makalenin tamamı Muhasebe Bilim Uzmanı Hakkı Akman ve Dr. Öğr. Üyesi

Ferhat Bitlisli tarafından eşit oranda katkı sağlamıştır

\section{Çıkar Beyanı}

$\mathrm{Bu}$ çalışmada herhangi bir potansiyel çıkar çatışması bulunmamaktadır.

\section{KAYNAKÇA}

Archer, S. (1996). The Ethics of Creative Accounting. Science and Engineering Ethics, 1(2), 55-70.

Bayındır, S. (2010). Türk Sermaye Piyasası Hukukunda Manipülasyon Suçu Doktora Tezi. İstanbul: Marmara Üniversitesi Sosyal Bilimler Enstitüsü, Hukuk Anabilim Dalı Kamu Hukuku Bilim Dali.

Bayırlı, R. (2006). Yaratıcı Muhasebe, Etik, Firma Değeri ve Örnek Bir Uygulama Doktora Tezi. Ankara: Gazi Üniversitesi Sosyal Bilimler Enstitüsü İşletme Anabilim Dalı Muhasebe Finansman Bilim Dalı.

Bekçi, İ., ve Avşarlıgil, N. (2011). Finansal Bilgi Manipülasyonu Yöntemlerinden Yaratıcı Muhasebe ve Bir Uygulama. Muhasebe Bilim Dünyası Dergisi, 13(2), 131-162.

Canbulut, G. (2008). Finansal Bilgi Manipülasyonu ve Örnek Bir Uygulama Yayınlanmamıs Yüksek Lisans Tezi. İzmir: Dokuz Eylül Üniversitesi Sosyal Bilimler Enstitüsü, GG̣letme Anabilim Dalı Finasman Bilim Dalı.

Coenen, T. (2008). Essentials of Corporate Fraud. New Jersey: John Wiley and Sons.

Çelik, T. (2010). Muhasebede Hata ve Hileler İle İlgili Muhasebe Meslek Mensupları Üzerinde Bir Araştırma. Niğde: T.C Niğde Üniversitesi Sosyal Bilimler Enstitüsü İşletme Aanabilim Dalı Muhasebe Finansman Bilim Dalı Yayımlanmamış Yüksek Lisans Tezi.

Çıtak, N. (2009). Hileli Mali Raporlamada Yaratıcı Muhasebe ve Bir Uygulama Doktora Tezi. İstanbul: Marmara Üniversitesi Sosyal Bilimler Enstitüsü, İşletme Anabilim Dalı Muhasebe Finansman Bilim Dali.

Dalğar, H., ve Pekin, S. (2011). Kurumsal Yönetim İle Finansal Tablo Manipülasyonu Arasındaki İlişki: İMKB Kurumsal Yönetim Endeksi'nde Yer Alan Şirketlerde Bir Araştırma. Mali 
Çözüm Dergisi 107., 19-43.

Daştan, A. (2010). Kurumsal Yönetim İlkeleri ve Kurumsal Muhasebe Etkileşimi. Türkiye Bankalar Birliği Bankacılar Dergisi(72).

Demir, V., ve Bahadır, O. (2007). Muhasebe Manipülasyonu Yöntem ve Teknikler. Mali Çözüm Dergisi 84, 103-119.

Dhaoui, A. (2010). What Does Matter In RveD Decentralization: Financial Performance Worry Or Intensive Earnings Management? 1-15.

Diana , B., ve Madalina, P. C. (2008). Is Creative Accounting A form of manipulation? University of Oradeor, Faculty of Economics, Department of Finance Accounting, Journal accredited(3), 935-940.

Genç, M., ve Köse, Y. (2018). Yaratıcı Muhasebe Uygulamaları ve Türkiye'de Bağımsız Denetçinin Sorumluluğu (Cilt Sonçağ Matbaacılık). Ankara: Akademisyen Kitabevi A.Ş.

Griffiths, I. (1986). Creative Accounting How to Make Your Profits What You Want Them to Be. Unwin Paperbacks. Great Britain.

Hsieh, L. F., ve Tsai, Y. T. (2006). Information Asymmetry. Creative Accounting And Moral Choice, An Apocalypse Of Procomp Informatic Ltd., Journal of American Academy Of Business, 2(6).

Jones, M. (2011). Introduction - Setting The Scene”. M. J. Jones (Ed.). Creative Accounting, Fraud and International Accounting Scandals. England: John Wiley ve Sons Ltd.

Jones, M. j. (2011). Creative Accounting, Fraud and International Accounting Scandals. Chichester, England.: John WileyveSons Inc. .

Kirschenheiter, M., ve Melumad, N. D. (2002). "Can Big Bath and Ear-nings Smoothing Co-Exist As Equilibri-um Financial Reporting Strategies?". Journal of Accounting Research 40 (3), 761796.

Küçüksözen, C. (2005). Finansal Bilgi Manipülasyonu : Nedenleri, Yönetemleri, Amaçları, Teknikleri, Sonuçları Ve IMKB ŞİRKETLERİ Üzerine Amprik Bir Çalışma. Ankara: T.C. Ankara Üniversitesi Sosyal Bilimler Enstitüsü İşletme Bölümü Anabilim Dalı.

McBarnet, D., ve Whelan, C. (1999). Creative Accounting and the Cross - Eyed Javelin Throver. England: Wiley Pr.

Mulford, C. W., ve Comiskey, E. E. (2002). The Financial Numbers Game, Detecting Creative Accounting Practice. U.S.A: John Wiley ve Sons.

Ocak, M., ve Güçlü, F. C. (2014). Muhasebe Manipülasyonu: Hile, Yaratıcı Muhasebe, Kar ve İzlenim Yönetimine İlişsin Kavramsal Çerçeve. Uluslararası Alanya İşletme Fakültesi Dergisi(6), 123-135.

Ömürgönülşen, M., ve Ömürgönülşen, U. (2009). Critical Thinking about Creative Accounting in the Face of a Recent Scnadal in the Turkish Banking Sector. Critical Perspectives on Accounting(20), 651-673.

Rezaee, Z. (2002). Financial Statement Fraud - Prevention and Detection. New York: John Wiley ve Sons, Inc.

Saltoğlu, M. (2003, 09 10). Yaratıcı Muhasebede Özel Amaçlı Şirketlerin Rolü ve Enron Örneği. Muhasebe ve Denetime Bakış, 107-116.

Smith, T., ve Hannah, R. (1991). Accounting for Growth. UK: UBS Phillips and Drew.

Srivastava, S., ve Tandon, A. (2014). Creative Accounting and Fraud : An Overview". Shrinkhala, $3(2), 24-28$.

Stolowy, H., ve Breton, G. (2000). A Review of Research on Accounts Manipulation. Paper for the Annual Congress of European Accounting Association, (s. 1-65). Munich, Germany.

Trussel, J. (2003). Assessing Potential Accounting Manipulation: the Financial Characteristics of Charitable Organizations with Higher than Expected Program-Spending Ratios. Sage Journals, 616-633.

Varıcı, İ., ve Er, B. (2013). Muhasebe Manipülasyonu ve Firma Performansı İlişkisi: İMKB Uygulamas1. Ege Akademik Bakış Dergisi, 13(1), 43-52.

Yayla, H. E. (2006). Güç Ve Yetki İlişkilerinin Muhasebe Bilgisi Kararları Üzerindeki Etkisi. Türkiye'deki Özel Hastaneler Üzerine Yapısal Bir Model Önerisi. Ankara: Ankara Üniversitesi, Sosyal Bilimler Enstitüsü, Doktora Tezi. 
Yörük, N., ve Doğan, E. (2009). Finansal Bilgi Manipülasyonu ve Finansal Bilgi Manipülasyonunun Belirlenmesine Yönelik IMKB'de Bir Uygulama. Ankara: Detay Yayınc1lık.

\section{SUMMARY}

Today, the importance of financial information and the number of people who need financial information are increasing day by day. A wide range of audiences such as managers, creditors, those who are willing to invest, suppliers and employees need financial information and make some decisions with the financial information provided. At this point, it is of great importance that the information provided by the enterprises is presented to financial information users in a reliable, comparable, appropriate, understandable, impartial, consistent and complete disclosure in line with Generally Accepted Accounting principles. However, it is observed that businesses sometimes avoid disclosing the financial information they provide in a realistic way. Financial information manipulation is carried out with the aim of decreasing borrowing costs, decreasing the political cost effect, increasing the effect of incentive premiums and raising stock prices. Manipulations to reduce borrowing costs; increasing the credibility of the company, reaching higher borrowing degree and lower borrowing costs, more flexible financial terms in loan agreements, etc. aims to bring out the benefits. Managers, who practice financial information manipulation in businesses, aim to impress those who are thinking of investing in the business, credit institutions that give credit and the relevant units of the state. In this way, it provides a positive thinking structure in the perceptions of those who make an investment decision about the enterprise. The manipulation of financial information is explained under two headings as ethical and improper methods (GAAP) "Generally Accepted Accounting Principles". Methods in accordance with "Generally Accepted Accounting Principles" are; profit management, profit stabilization, large cleanliness accounting, aggressive accounting and creative accounting. Manipulations applied in violation of Generally Accepted Accounting Principles are explained as fraudulent financial reporting.

In this study, first of all, the concept of Financial Information Manipulation is mentioned, and the types and methods of financial information manipulation are explained. In the next stage, the concept of Creative Accounting, which is a type of financial information manipulation, and Creative accounting methods are emphasized. In the study, it is also included in the literature research on the concept of creative accounting.

In the research part of the study, frequency analysis was made regarding the responses of the accounting professionals to the expressions to determine their thoughts on creative accounting. In the analysis results regarding the opinions of the accounting professionals about creative accounting, it was seen that the majority of the members of the profession did not have information, resorting to creative accounting practices mean paying less tax, and the vast majority of them knew the concepts of error and fraud very well. In addition, it has emerged that the majority of the professions participating in the research are not subject to independent audit 
of their taxpayers, do not or will rarely examine the audited financial reports that they intend to purchase the stocks of an enterprise. The average of the expressions related to the frequency of encounters with cheating markers and the demographic characteristics of the profession members developed by Çelik (2010) were subjected to the Independent-Samples T Test and One-Way ANOVA. As for the test results for cheating tokens; In terms of city and gender, it was determined that there was no difference between members of the profession in terms of the frequency of encountering fraud tokens, and that there were significant differences in terms of the frequency of encountering cheating tokens in terms of the education level, age, professional experience and number of taxpayers. 